\title{
RUNX1/MECOM Fusion Gene
}

National Cancer Institute

\section{Source}

National Cancer Institute. RUNX1/MECOM Fusion Gene. NCI Thesaurus. Code C99295.

A fusion gene ( $5.9 \mathrm{~kb})$ that results from a chromosomal translocation $\mathrm{t}(3 ; 21)(\mathrm{q} 26 ; \mathrm{q} 22)$

which fuses the first 5 exons of the RUNX1 gene to most of the MECOM gene. This rearrangement is associated with acute myelogenous leukemia, chronic myelogenous leukemia and myelodysplasic syndrome. 